\title{
KESELAMATANDAN KESEHATAN KERJA SEBAGAI BAGIAN DARI KAMPUS DAN PEMBERDAYAANNYA
}

\author{
Oleh:
}

\author{
Andreas. M. Saragih ${ }^{1)}$ \\ Semangat Marudut Tua Debataraja 2) \\ Universitas DarmaAgung, Medan ${ }^{1,2}$ \\ E- mail: \\ $\frac{\text { andreassaragih1970@gmail.com }}{\text { semangat_raja@yahoo.com }}^{\text {() }}{ }^{1)}$
}

\begin{abstract}
Occupational Safety and Health at our Campus is all activities to guarantee and protect the safety and health of students and all employees through efforts to prevent accidents and diseases caused by the work of employees / lecturers and student recovery. The risks faced by employees and students in lectures for example are accidents in driving, falling off on campus due to playing or playing sports, lack of sleep due to activities, natural disasters, earthquakes, floods, fires, and so forth. The Need for Policy, Planning, Implementation and Operational, Inspection and corrective action, Management Review, and Continuous Improvement for the OSH program done on campus. OSH activities certainly involve all students, lecturers, and all staff, and employees on campus so that OSH is cultured and not just material in lectures on campus.
\end{abstract}

Keywords: occupational safety and health, risk, policy, planning, implementation and operation, inspection and corrective actions, management review, continuous improvement, osh

\begin{abstract}
ABSTRAK
Keselamatandan Kesehatan Kerja di Kampus kita adalah segala kegiatan untuk menjamin dan melindungi keselamatan dan kesehatan mahasiswa dan semua karayawan melalui upaya pencegahan kecelakaan dan penya kita kibat pekerjaan karyawan/dosen dan perkulihan mahasiswa. Resiko yang dihadapi karyawan dan mahasiswa dalam perkuliahan sebagai contoh yaitu kecelakaan dalam berkendaraan, jatuh tergelincir di dalam kampus karena bermain atau pun berolah raga, kurang tidur karena aktifitas, bencana alam gempa bumi, banjir, kebakaran, dan lain sebagainya. Perlunya Kebijakan (Policy), Perencanaan (Planning), Pelaksanaan dan Operasional (Implementation and Operational), Pemeriksaan dan tindakan perbaikan (Checking and Corrective Action), Tinjauan Manajemen (Management Review), dan Perbaikan terus - menerus (Continual Improvement) agar program K3 terlaksana di kampus. Kegiatan K3 tentunya melibatkan seluruh
\end{abstract}


mahasiswa, dosen, danseluruh staff, sertakaryawan dikampus agar K3 membudaya dan bukan hanya materi dalam perkuliahan di dalam kampus.

Keyword: keselamatan dan kesehatan kerja, resiko, kebijakan, perencanaan, pelaksanaan dan operasional, pemeriksaan dan tindakan perbaikan, tinjauan manajemen, perbaikanterus-menerus, budaya $\mathrm{k} 3$

\section{PENDAHULUAN}

Persoalan muncul Ketika suatu kampus mengalami resiko kecelakaan pada mahasiswa di dalam kampu sseperti Ketika berolah raga ada yang tergelincir dan jatuh, ad anya kebakaran di kampus, adanya gempa bumi yang berdampak di kampus, adanya penyakit Demam berdarah di lingkungan kampus, dan sebagainya pada mahasiswa, dosen dan staff kampus. Banyak kasus kalua mau kita usut satu persatu dalam kegiatan kampus yang berdampak kepada Keselamatan dan Kesehatan Kerja. Tentunya perlu dikendalikan hal resiko tersebut agar terdapat pengurangan atau meniadakan resiko tersebut.

Dalam pelaksanaan kesempatan untuk bekerja dengan diikuti Langkah yang tepat untuk menimba ilmu pada satu institusi maupun kondisi yang baik akan menciptakan kenyamanan belajar dan bekerja dilingkungan kampus/tempat kerja masing-masing. Purba D \& Sihombing H (2020), Pnajaitan J, Simangunsong I, Damanik D \& Hulu A (2020).

METODE PELAKSANAAN

Flow Chard Model Penerapan

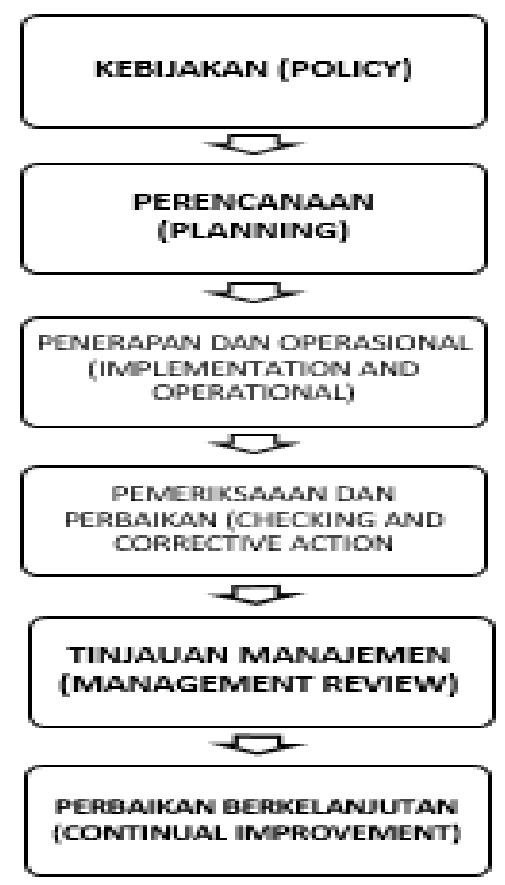

Gambar 1. Flowchart penelitian

\section{HASIL DAN PEMBAHASAN Kebijakan (Policy)}

Kebijakan yang dilakukan Negara yaitu:

Pelaksanaan K3 sesuai UU 1/1970 secara eksplisit merupakan pelaksanaan K3 secara sistem

SMK3 dikeluarkan sejak 1996 melalui Permenaker No. 05/Men/1996

Di Internasional perkembangan system manajemen K3 mulai berkembang melalui ILO GuidlineTahun 2001 
Ohsas dikembangkan pada tahun 2001

Dan setiap perusahaan/kampus wajib membuat kebijakan- kebijakan yang mengarah kepada Keselamatan dan Kesehatan Kerja pada tempat kerja/kampus yang mengarah kepada Peraturan Pemerintah agar resikoresiko yang dihadapi bisa mengerucut atau nol resiko baik itu terkait manajemen, kebakaran, gempa bumi, P3K, dll.

\section{PERENCANAAN (PLANNING)}

Perencanaan identifikasi bahaya, penilaian dan pengendalian resiko harus memenuhi kebijakan K3 yang ditetapkan. Prosedur perencanaan identifikasi bahaya, penilaian resiko, dan pengendaliannya harus ditetapkan dan didokumentasikan agar keselamatan dan kesehatan bisa terkendali.pentingnya organisasi $\mathrm{K} 3$ dibentuk agar pelaksanaan rencana dikerjakan dengan mudah, terkoordinir. Organisasi harus menyusun dan memelihari prosedur tentang identifikasi peraturan perundangan dan persyaratan lainnya yang dibutuhkan dalam kegiatan organisasi dalam K3. Organisasi K3 harus menyusun dan memelihara tujuan dan sasaran K3, memungkinkan mempertimbangkan resiko, teknologi, kemampuan keuangan, dan persyaratan. Dalam tujuan dan sasaran sekurangkurangnya harus memenuhi kualifikasi:

1. Dapat diukur

2. Satuan indicator pengukuran
3. Sasaran pencapaian

4. Dan jangka waktu pencapaiannya.

Tujuan dan sasaran K3 harus konsisten terhadap kebijakan K3 termasuk kebijakan tentang perbaikan berkelanjutan.

PENERAPAN

DAN

OPERATIONAL

(IMPLEMENTATION

AND

OPRATIONAL)

Secara efektif dengan mengembangkan kemampuan dan mekanisme pendukung yang diperlukan untuk mencapai kebijakan, tujuan dan sasaran K3. Dalam memenuhi ketentuan kebijakan dan planning, organisasi K3 harus membuat prosedur dan menyediakan biaya, sehingga dapat dipantau keefktifannya seperti:

1. Sumber daya yang memadai sesuai tingkat keperluannya

2. Melakukan identifikasi kompetensi kerja termasuk pelaksanaan pelatihan yang dibutuhkan.

3. Mengkomunikasikan informasi K3 secara efektif

4. Membuat ketentuan/peraturan untuk mendapatkan saran- saran dari para ahli K3

5. Membuat ketentuan/peraturan untuk pelaksanaan konsultasi dan keterlibatan mahasiswa/karyawan.

6. Membuat dokumentasi dan pelaporan daily, weekly, dan monthly 
Pengukuran (evaluasi) dan peningkatan kinerja K3 didasarkan pada ketentuan yang telah ditetapkan berupa parameter kinerja, cara penilaian dan pengukuran. Misalnya:
1. Tingkat pemahaman pengetahuan dan partisipasi pekerja dalam kegiatan K3 termasuk partisipasi pengunjung/tamu/subkontraktor/ vendor/mitra
kerja/mahasiswa/staff dll yang terkait pelaksanaan kerja konstruksi di kampus/tempat kerja

2. Statistik angka insiden/kecelakaan

3. Jumlah jam kerja yang hilang

\section{CHECKING AND CORRECTIVE ACTION}

Pemeriksaan yaitu:

1. Prosedur pemeriksaan dapat berupa inspeksi dan audit yang bersifat internal, pemeriksaan harus dilakukan oleh petugas yang mempunyai kompetensi di bidang K3 yang sesuai.

2. Pemeriksaan yang bersifat inspeksi dapat dilaksanakan harian (daily), mingguan (weekly), bulanan (monthly) yang harus dijalankan secera tetap dan kontinu untuk mempertahankan yang telah dicapai.

3. Pemeriksaan bersifat audit dilaksanakan secara berkala 3 atau 6 bulan sekali. Ketentuan ini berlaku mengikuti ketentuan/standart audit yang diberlakukan pada umumnyaoleh badan internal organisasi badan auditor.

4. Pemeriksaan dilaksanakan oleh petugas yang mempunyai kompetensi di bidang kerjanya secara sertifikasi yang diberi kewenangan dalam bidang K3.

5. Kegiatan pemeriksaan dapat dimulai dan pengendalian kegiatan material pergudangan barang masuk dan keluar, penempatan/ penyimpanan, pemindahan, pemasangan, pemeliharaan, pengolahan, penanganan kesehatan dan penyakit akibat kerja.

Tindakan perbaikan yaitu:

1. Perbaikan atas temuan ketidaksesuaian (non conforming) K3

2. Pelaksanaan K3 yang tidak sesuai dengan standart

3. Rekomendasi hasil inspeksi, pengujian dan commissioning

\section{MANAGEMENT REVIEW}

Tinjauan manajemen harus dilakukan secara teratur untuk peningkatan penerapan K3 secara berkelanjutan (Contonual Improvement). Hal ini dapat dipastikan dan didokumentasikan serta mudah ditelusuri bila diperlukan untuk pengembangan K3. Pimpinan puncak dalam manajemen dalam organisasi K3 harus mengevaluasi kinerja K3 secara periodic sesuai yang ditentukan, 
untuk menjamin kesesuaian dan efektifitasnya.

Dalam evaluasi ini harus disediakan informasi yang memadai sehingga manejemen organisasi K3 bisa melakukan evaluasi dengan tepat. Tinjauan manajemen ditujukan untuk memungkinkan dilakukan perubahan terus- menerus dan sasaran yang hal yang lain- lain dalam system keselamatan dan kesehatan kerja pada tempat kerja/kampus di dalam kerangka system K3 dan perbaikan berkelanjutan.

\section{CONTINUAL IMPROVEMENT}

\begin{tabular}{|c|c|}
\hline Seca & berkala \\
\hline $\begin{array}{l}\text { tinjauan } \\
\text { manajemen }\end{array}$ & $\begin{array}{c}\text { manajemen } \\
\text { puncak }\end{array}$ \\
\hline
\end{tabular}
manajemen telah berjalan baik sesuai harapan, dan jika perlu segera dilakukan tindakan koreksi atau perbaikan menuju peningkatan berkelanjutan.

\section{Perbaikan}

mutu

berkelanjutan (continuous quality improvement) adalah sebuah siklus proses terstruktur untuk memperbaiki sistem dan proses kerja dalam suatu organisasi K3 atau kegiatan K3. Siklus ini mencakup identifikasi area yang berpeluang untuk perbaikan, mendefinisikan masalah dalam area tersebut, menguraikan urutan kegiatan (proses) yang terjadi di area tersebut, menetapkan hasil yang diinginkan dari proses dan persyaratan yang dibutuhkan untuk mencapainya, memilih langkah-

langkah spesifik dalam proses belajar, mengumpulkan dan menganalisis data tentang proses, dan tindakan perbaikan, dan pemantauan hasil tindakan tersebut.

\section{SIKLUS K3}

Siklus K3 dibuat bertujuan:

- Penyampaian informasiinformasi K3 kepada seluruh personil K3

- $\quad$ Evaluasi oleh manajemen

- $\quad$ Penentuan program- program

kerja yang bersifat strategis

\section{Siklus K3}

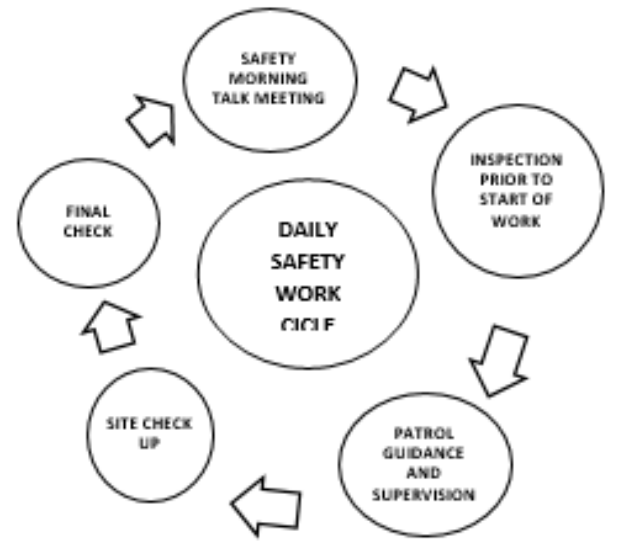

Gambar 2. Siklus K3

\section{KESIMPULAN}

Dapat disimpulkan bahwa Keselamatan dan Kesehatan Kerja dapat diterapkan pada Mahasiswa bukan hanya sebagai materi kuliah, melainkan dikembangkan pada kolasi Kampus/tempat kerja dll. Jadi tujuan dibuat K3 pada Kampus/ tempat kerja yaitu: 
1. Meningkatkan efektifitas perlindungan keselamatan dan kesehatan kerja yang terencana, terukur, terstruktur, dan terintegrasi pada Kampus/tempat kerja.

2. Mencegah dan mengurangi kecelakaan kerja dan penyakit akibat kerja dengan melibatkan unsur manajemen, mahasiswa, pekerja/buruh, dan/atau serikat pekerja/serikat buruh; serta

3. Menciptakan tempat kerja yang aman, nyaman, dan efisien untuk mendorong produktivitas dalam belajar dan bekerja.

Kampus/ tempat kerja harus diterapkan K3 secara perlahan dan pasti dibentuk organisasi K3 untuk mencegah/mengurangi kecelakaan kerja dan penyakit akibat kerja. Sehingga diperoleh tempat kerja/kampus yang nyaman, aman dan produktif.

\section{DAFTAR PUSTAKA}

Harington J. M, Gill F. S, Occupational Health (Pocket Consultant), $3^{\text {rd }}$ edition, Blackwall Science ltd, 1994

Goelzer, Ferrari B, Control Technology for Occupational Safety and Health, in $L$. Parmeggiani, Encyclopedia of Occupational Health and Safety, Vo. 2, Geneva, ILO, 2002

Departemen Tenaga Kerja Republik Indonesia, Himpunan Peraturan dan Perundangundangan Keselamatan dan Kesehatan Kerja, Direktorat
Jenderal Hubungan Industrial dan Pengawasan Tenaga Kerja

Semiloka SMK3, Sektor Konstruksi dalam menunjuang Otonomi Daerah dan Globalisas, 2002

Departemen Tenaga Kerja Republik Indonesia, Seminar Sistem Manajemen Keselamatan dan Kesehatan Kerja di Sektor Industri Konstrusi, 2004

Sukamakmur Pk, MSc, Higiene Perusahaan dan Kesehatan Kerja, Gunung Agung, Jakarta 1985.

Purba, D., \& Sihombing, H. (2020). IMPROVING

STUDENTS'WRITING

ABILITY IN DARMA
AGUNG

Jurnal Darma Agung, 28(1), 145-155.

doi:10.46930/ojsuda.v28i1.602

Panjaitan, J., Simangunsong, I., Damanik, D., \& Hulu, A. (2020). PENGARUH MODEL PEMBELAJARAN

KOOPERATIF TIPE TEAM ASSISTED

INDIVIDUALIZATION (TAI)

BERBANTUAN

EKSPERIMEN TERHADAP KETERAMPILAN PROSES

SAINS. Jurnal Darma Agung, 28(1), $52 \quad-\quad 63$. doi:10.46930/ojsuda.v28i1.460 